\title{
An efficient autometallography approach to localize lead at ultra-structural levels of cultured cells
}

\author{
Han Song ${ }^{1,2}$, Gang Zheng ${ }^{2}$, Xue-Feng Shen ${ }^{2}$, Zai-Hua Zhao ${ }^{2}$, Yang Liu ${ }^{2}$, \\ Yang Liu ${ }^{3}$, Ying-Ying Liu ${ }^{4}$, Jun-Jun Kang ${ }^{4}$, Jing-Yuan Chen ${ }^{1,2}$, \\ Wen-Jing Luo ${ }^{2}$ \\ 1 Department of Health Service, PLA General Hospital, Beijing 100853, China \\ 2 Department of Occupational and Environmental Health and the Ministry-of-Education's Key Laboratory of Hazard \\ Assessment and Control in Special Operational Environment, School of Public Health, Fourth Military Medical \\ University, Xi'an 710032, China \\ 3 Department of Neurology, Xijing Hospital, Fourth Military Medical University, Xi'an 710032, China \\ 4 Institute of Neurosciences, Fourth Military Medical University, Xi'an 710032, China
}

Received: 1 June 2020 / Accepted: 13 July 2020 / Published online: 28 September 2020

\begin{abstract}
Understanding the precise intracellular localization of lead $(\mathrm{Pb})$ is a key in deciphering processes in $\mathrm{Pb}$ induced toxicology. However, it is a great challenge to trace $\mathrm{Pb}$ in vitro, especially in cultured cells. We aimed to find an innovative and efficient approach to investigate distribution of $\mathrm{Pb}$ in cells and to validate it through determining the subcellular $\mathrm{Pb}$ content. We identified its ultra-structural distribution with autometallography under electron microscopy in a choroidal epithelial Z310 cell line. Electron microscopy in combination with energy-dispersive X-ray spectroscope (EDS) was employed to provide further evidence of $\mathrm{Pb}$ location. In addition, $\mathrm{Pb}$ content was determined in the cytosol, membrane/ organelle, nucleus and cytoskeleton fractions with atomic absorption spectroscopy. Pb was found predominantly inside the nuclear membranes and some was distributed in the cytoplasm under lowconcentration exposure. Nuclear existence of $\mathrm{Pb}$ was verified by EDS under electron microscopy. Once standardized for protein content, $\mathrm{Pb}$ percentage in the nucleus fraction reached the highest level (76\%). Our results indicate that $\mathrm{Pb}$ is accumulated mainly in the nucleus of choroid plexus. This method is sensitive and precise in providing optimal means to study the ultra-structural localization of $\mathrm{Pb}$ for in vitro models. In addition, it offers the possibility of localization of other metals in cultured cells. Some procedures may also be adopted to detect target proteins via immunoreactions.
\end{abstract}

Keywords Lead, Autometallography, Subcellular fraction, Energy-dispersive X-ray spectroscope, Electron microscopy

\section{INTRODUCTION}

Neurotoxicity due to lead $(\mathrm{Pb})$ accumulation in specific brain areas causes a wide variety of symptoms including decreased intelligence quotient, cognitive deficits, poor attention span and increased aggression (Boucher et al. 2012; Calderón et al. 2001; Needleman et al. 1996; Tong

$\bowtie$ Correspondence: jy_chen@fmmu.edu.cn (J.-Y. Chen), et al. 1998). The mechanism of Pb-induced disturbance of neuronal functions included interfering with neurotransmitter release, disrupting the function of GABAergic, dopaminergic, and cholinergic systems, inhibiting N-methyl-D-aspartic acid receptor (NMDAR) and NMDAR-mediated signaling pathways that are necessary for learning, memory and synaptic plasticity (Akinyemi et al. 2019; Basha et al. 2012; Wang et al. 2016; Wirbisky et al. 2014). 
The pathways by which $\mathrm{Pb}$ enters into the brain parenchyma are attributed to the breakdown of brain barriers including the blood-brain barrier (BBB) and blood-cerebrospinal fluid (CSF) barrier (BCB) (Shi and Zheng 2007; Song et al. 2014; Wang et al. 2007). In studying $\mathrm{Pb}$-induced toxicity in the $\mathrm{BCB}$, in vitro experiments have played a crucial role in delineating its breakdown, inhibition of production and secretion of transthyretin and accumulation of beta-amyloid (Behl et al. 2010; Shi and Zheng 2007; Zheng et al. 1999). Additionally, manipulations of nucleic acid levels or protein kinase activity in in vitro models, especially in cell cultures, have helped to unravel key regulatory molecules associated with Pb's effects. In our previous study on Pb-induced breakdown of the BBB in rat brain microvascular endothelial RBE4 cells, reduction of brain barrier tight junctional proteins was regulated by activation of tyrosine kinase Src via chaperon glucoseregulated protein of $78 \mathrm{kDa}$ (GRP78) (Song et al. 2014). However, the intracellular $\mathrm{Pb}$ localization has been ignored in exploring the molecular mechanisms of $\mathrm{Pb}$ toxicity.

Approaches of $\mathrm{Pb}$ localization in cells may be classified into three modalities: intuitive observation in combination with energy-dispersive X-ray spectroscope (EDS), isotopic tracer labeling, and autometallography (AMG). In the 1970s, high-dose $\mathrm{Pb}$ was used in numerous studies. This metal was visualized directly as nuclear inclusion bodies in renal tubular cells of rats (Moore and Goyer 1974). Cytoplasmic or intranuclear inclusions observed in macrophages and astrocytes of $\mathrm{Pb}$-implanted rat brains were further studied with EDS (Shirabe and Hirano 1977). To localize $\mathrm{Pb}$ in the developing rat cerebellum, autoradiographs were prepared by both light microscopy and electron microscopy from cerebellar tissues after injection of radioactive $\mathrm{Pb}$ $\left({ }^{210} \mathrm{~Pb}\right)$ (Thomas et al. 1973). Another radioactive $\mathrm{Pb}$ isotope, ${ }^{203} \mathrm{~Pb}$, was used to test the binding capacity of nuclear and inclusion body fractions induced by $\mathrm{Pb}$ pretreatment (Oskarsson and Fowler 1985). AMG, an extremely precise and sensitive metal tracing cytochemical technique, has been used to detect gold, silver, mercury, bismuth or zinc (Zn) with sulfur and/or selenium (Danscher and Stoltenberg 2006). Electrons released from hydroquinone molecules adhere to the metal sulfides or metal selenides. The silver ions are attracted to catch the electrons and aggregate around the metals as silver atoms, which can be visualized as black silver deposits (BSDs; Danscher and MøllerMadsen 1985). Under light microscopy, BSDs were found in the frontal epithelium of the gill filament in the $\mathrm{Pb}$-exposed mussels (Domouhtsidou and Dimitriadis 2000). BSDs also existed in the dense bodies of the epithelial cells in Mytilus galloprovincialis under electron microscopy after 30- and 60-day $\mathrm{Pb}$ exposure (Dimitriadis et al. 2003). To our knowledge, methods to localize $\mathrm{Pb}$ in cultured cells have yet to be developed.

The choroid plexus, a highly vascularized tissue, constitutes the BCB. One side of the BCB confronts blood circulation, and the other side faces CSF isolated from blood stream in cerebral compartments. As a barrier between the blood and CSF, choroid plexus not only plays a vital role in regulating the homeostasis of the central nervous system by rigorously restricting access of substances from the blood to the CSF, but also facilitates neuronal development by producing and secreting growth factors, peptides, neurotrophins, hormones, and protein stabilizers, such as transthyretin (Chodobski and Szmydynger-Chodobska 2001; Levine 1987; Zheng 2001). Choroid plexus was the target for many heavy metals including $\mathrm{Pb}$ in previous studies. $\mathrm{Pb}$ level increased with age in human choroid plexus (Friedheim et al. 1983). Compared with brain cortex, 100 times increment of $\mathrm{Pb}$ was reported in human choroid plexus (Manton et al. 1984). Moreover, radiolabeled lead nitrate $\left({ }^{210} \mathrm{~Pb}\right)$ was concentrated about $>70$ times in choroid plexus than brain of adult pigs (O'Tuama et al. 1976). Furthermore, accumulation of $\mathrm{Pb}$ was both dose-dependent and time-related in an acute $\mathrm{Pb}$ exposure study (Zheng et al. 1991). Thus, choroid plexus, not other tissues, was chosen as the research target because of its highest power of $\mathrm{Pb}$ accumulation.

A choroidal epithelial Z310 cell line has been established from murine choroid plexus (Zheng and Zhao 2002). The purpose of the present study was to develop a novel approach to investigate the localization of $\mathrm{Pb}$ in Z310 cells. The results from this study provide additional evidence for nuclear $\mathrm{Pb}$ in mediating BCB toxicity.

\section{RESULTS}

\section{$\mathrm{Pb}$ localization in ultra-structural levels}

The choroidal epithelial Z310 cell line was used as choroids plexus in vitro model. $10 \mu \mathrm{mol} / \mathrm{L}$ was chosen as a working concentration for $\mathrm{Pb}$ exposure (Shi and Zheng 2007). To visualize the cellular distribution of $\mathrm{Pb}$ upon $10 \mu \mathrm{mol} / \mathrm{L}$ treatment in Z310 cells, we employed electron microscopic AMG technique and recorded the key steps (Fig. 1). Interestingly, particles were found predominantly inside the nuclear membranes and some of them were distributed in the cytoplasm (Fig. 2). As expect, nuclear accumulation of $\mathrm{Pb}$ were not observed in $10 \mu \mathrm{mol} / \mathrm{L} \mathrm{Pb}$-treated cells under TEM without AMG 
A

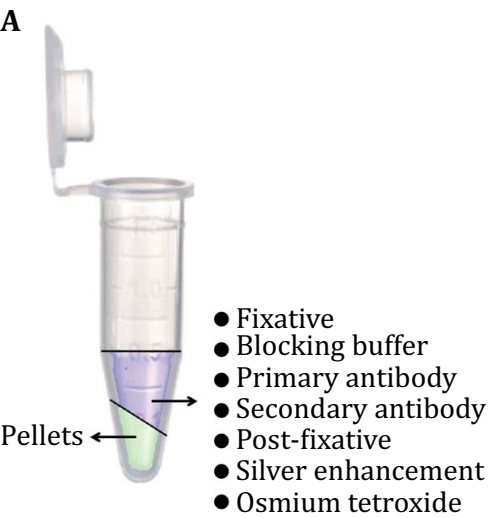

D

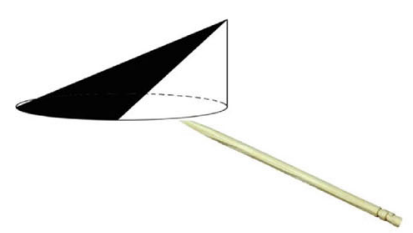

F

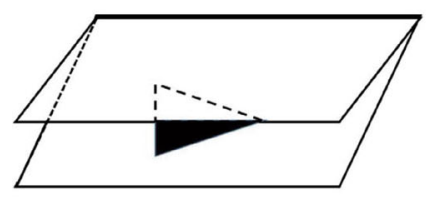

B

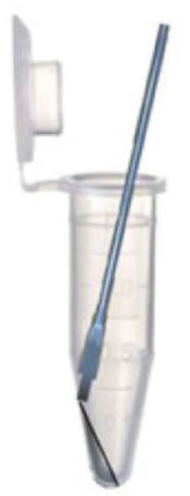

C

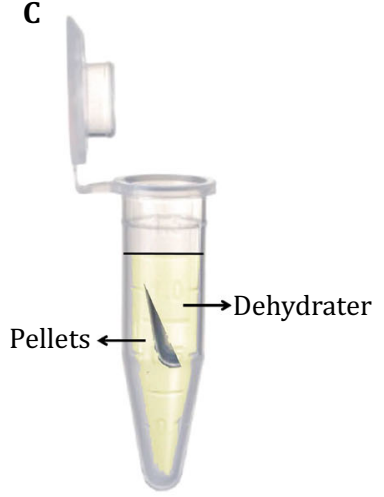

$\mathbf{E}$

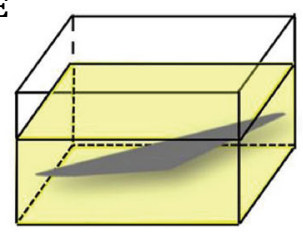

G

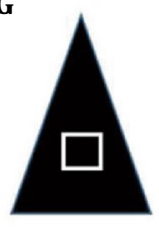

H

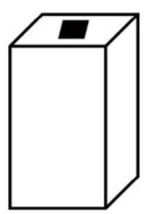

I

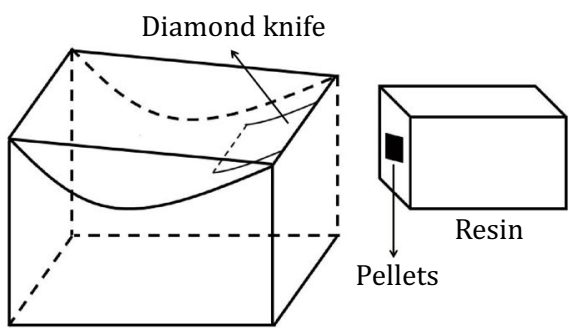

Ultra-microtome
J

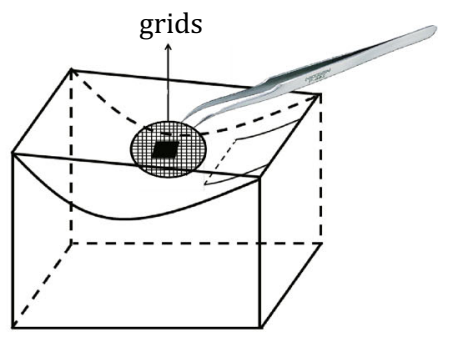

Fig. 1 Additional illustration of operational skills. A Incubation with pre-fixative, blocking buffer, primary antibody, secondary antibody, post-fixative, reagent of silver enhancement and osmium tetroxide. B Detachment from above of the pellets. C Dehydration with graded ethanol and acetone. D Transfer via the pellets' bottom with toothpicks. E Immersion in soak solution. F Placement between two boards and aggregation of embedding medium. G, $\mathbf{H}$ Cut of small pieces from the pellets indicated by the white square in the black triangle (G) and stickup on the resins (H). I Ultrathin sections by the diamond knife of ultramicrotome. J Transfer the sections with the grids squeezed by tweezers

staining. The "invisible" $\mathrm{Pb}$ in the nucleus, however, could be detected by EDS (Fig. 3A). Wt $\%$ and at $\%$ of five metal elements including $\mathrm{Pb}$, manganese $(\mathrm{Mn})$, iron $(\mathrm{Fe})$, $\mathrm{Zn}$ and calcium $(\mathrm{Ca})$ were calculated simultaneously. In the control group, the nuclear area outlined with red square frame consisted of $\mathrm{Fe}$ (wt\%, 37.26\%; at\%, $41.01 \%$ ) and $\mathrm{Zn}$ (wt\%, 62.74\%; at\%, 58.99\%). In the $10 \mu \mathrm{mol} / \mathrm{L}$ group, the area consisted of four elements including $\mathrm{Fe}, \mathrm{Zn}, \mathrm{Pb}$ and $\mathrm{Ca}$. $\mathrm{Pb}$ content (wt\%, 16.39\%; at $\%, 5.12 \%$ ) was far lower than $\mathrm{Fe}$ (wt\%, 64.75\%; at $\%$, 

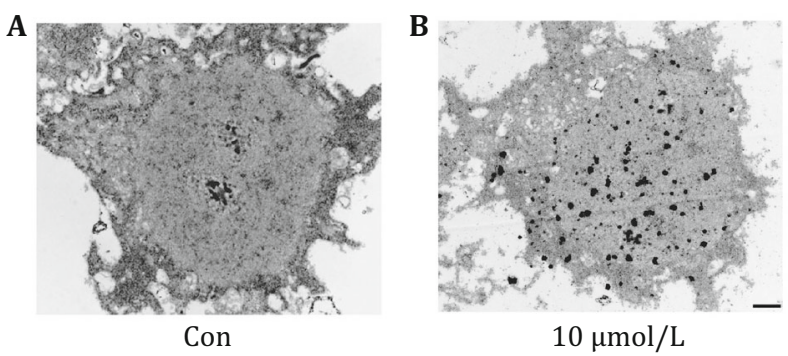

Fig. $2 \mathrm{~Pb}$ localization detected by electron microscopic AMG staining in Z310 cells after treatment of 0 (Con) (A) or $10 \mu \mathrm{mol} / \mathrm{L}$ of $\mathrm{Pb}(\mathbf{B})$ for $24 \mathrm{~h}$. Scale bar is $1 \mu \mathrm{m}$

$75.12 \%)$ and $\mathrm{Zn}(\mathrm{wt} \%, 17.15 \%$; at $\%, 17 \%)$. The weight of $\mathrm{Zn}$ decreased from $62.74 \%$ to $17.15 \%$, but $\mathrm{Fe}$ increased from $37.26 \%$ to $64.75 \%$ (Fig. 3B).

To verify the EDS analyses of low-level $\mathrm{Pb}$ exposure, $200 \mu \mathrm{mol} / \mathrm{L}$, which reduces cell viability significantly, was chosen as positive control. After 24-h treatment, large particles with high density contained in the lysosome were analyzed by EDS (Fig. 4A). For at\%, Mn, Fe, $\mathrm{Zn}, \mathrm{Pb}$ and $\mathrm{Ca}$ accounted for $41.22 \%, 26.05 \%, 14.14 \%$, $12.69 \%$ and $5.09 \%$, respectively. For wt $\%, \mathrm{Mn}, \mathrm{Fe}, \mathrm{Zn}$, $\mathrm{Pb}$ and $\mathrm{Ca}$ accounted for $30.16 \%, 19.38 \%, 12.31 \%, 35 \%$ and $3.15 \%$, respectively (Fig. 4B).

\section{$\mathrm{Pb}$ measurement in subcellular fractionation}

To verify the findings in electron microscopic AMG staining, we next investigated $\mathrm{Pb}$ content in subcellular fractions of Z310 cells. Firstly, cellular morphology was captured under the light microscopy before extraction of cytosol, membrane/organelle, nucleus and cytoskeleton fractions (Fig. 5A). Protein content was measured in these four fractions $6,12,24$ or $48 \mathrm{~h}$ after $\mathrm{Pb}$ exposure. Protein percentage of cytosol and membrane/organelle fractions was larger than nucleus and cytoskeleton (Fig. 5B). However, Pb was mostly accumulated in cytosol (43\%) and nucleus (41\%) fractions at $24 \mathrm{~h}$ (Fig. 5C). Once corrected for protein content, $\mathrm{Pb}$ percentage in the nucleus fraction reached the highest level $(76 \%$, Fig. 5D). In the nucleus fraction, $\mathrm{Pb}$ decreased to a lower level at $12 \mathrm{~h}$ after reaching the peak at $6 \mathrm{~h}$ and was maintained in a relatively unchanged condition from 12 to $48 \mathrm{~h}$ (Fig. 5E). The effectiveness of this novel approach was further verified by the evidence of nuclear $\mathrm{Pb}$ accumulation from quantitative perspectives.

\section{Localization of molecules in ultra-structural levels}

Meanwhile, this protocol may also be used as a reference for immunogold-silver staining. Detailed procedures, addressing both temperature and time requirements are shown in the flow chart (Fig. 6A). We determined the localization of CD20 in the B-lymphocytes from human peripheral venous blood (Fig. 6B) and GRP78 in RBE4 cells (Fig. 6C). CD20 was exclusively expressed on the surface of B-lymphocytes, while GRP78 was localized to the lumen of endoplasmic reticulum.

\section{DISCUSSION}

AMG is an effective and precise cytochemical technique to study the accumulation of metals in an organ and its cells. Although AMG was widely used in previous studies to visualize the distribution of metals, AMG granules in cultured cells are difficult to localize under electron microscopy, because junctional molecules fail, in comparison to tissue samples, to provide a threedimensional structure. In the current study, we investigated the effectiveness of a novel approach on the localization of low-level $\mathrm{Pb}$ in cultured cells at ultrastructural level. Based on our previous experiences in carrying out immunogold staining techniques for cell samples (Song et al. 2014; Kang et al. 2013), we designed this simple and efficient pre-embedding AMG method that does not require special devices or freezing techniques. In the present study, we found that $\mathrm{Pb}$ mainly accumulated in the nucleus of the established choroidal epithelial cell line. The newly developed AMG protocol is sensitive and precise in providing optimal means to study the ultra-structural localization of $\mathrm{Pb}$ in cultured cells. In addition, some key procedures may also be referred to detect target proteins via immunoreaction in cultured or isolated cells under TEM.

Using this approach, we found nucleus seemed to be an important container for $\mathrm{Pb}$. To further validate the phenomenon, the intracellular $\mathrm{Pb}$ distribution was directly determined in relatively well-isolated subcellular fractions. Total nuclear $\mathrm{Pb}$ was lower than that in the cytosol, but higher than that in other fractions. After standardization for protein levels, the percentage of $\mathrm{Pb}$ content in the nucleus was the highest, indicating that 
A

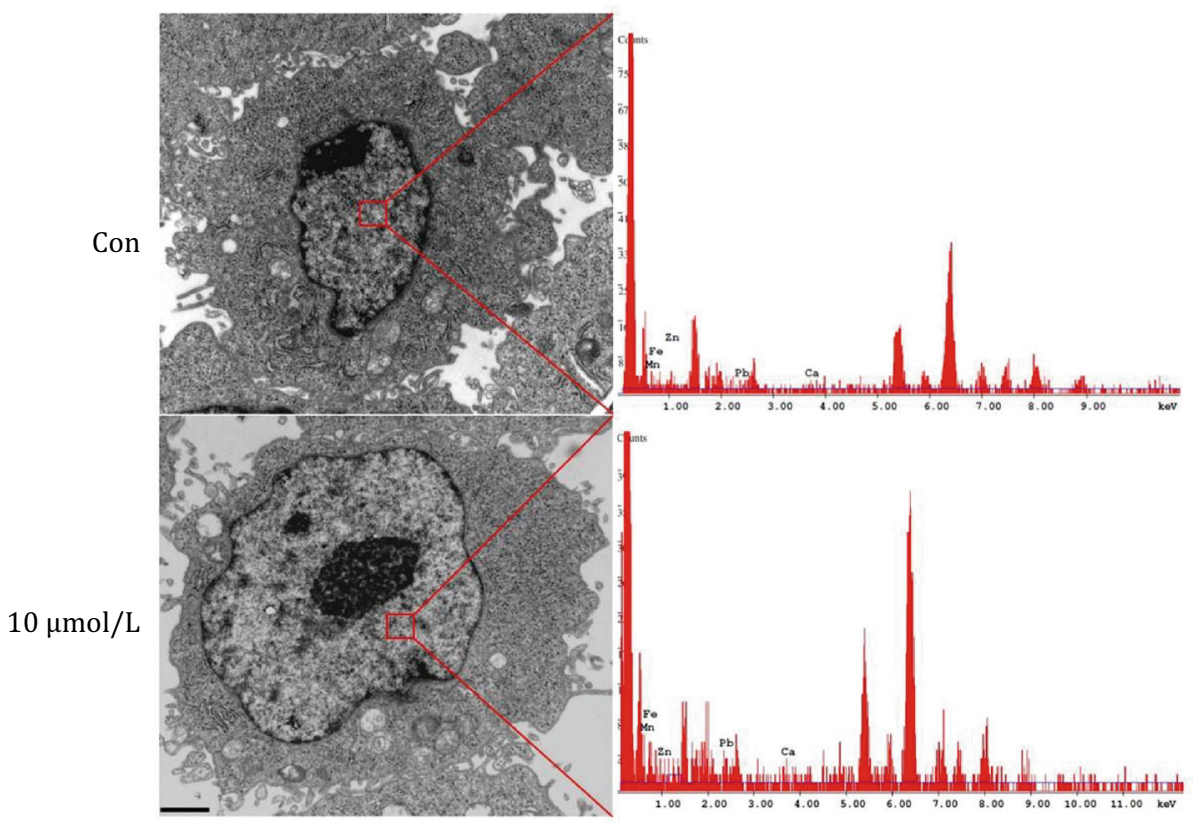

B

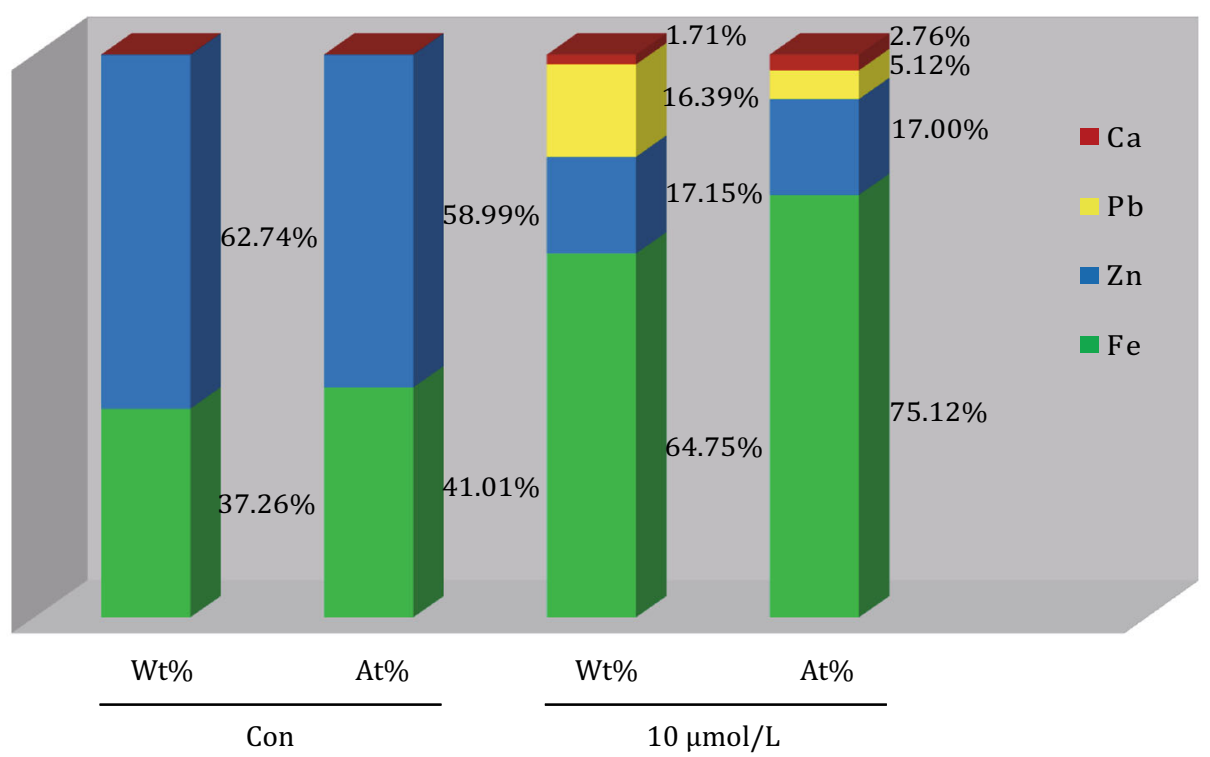

Fig. 3 EDS analysis of the nucleus in Z310 cells treated with low-dose Pb. A Cell morphology under TEM after treatment of 0 (Con) or $10 \mu \mathrm{mol} / \mathrm{L}$ of Pb for $24 \mathrm{~h}$ (left). EDS analysis of nuclear areas marked with the red frames (right). Scale bar is $1 \mu \mathrm{m}$. B Calculation of wt\% and $\mathrm{at} \%$ of $\mathrm{Pb}, \mathrm{Mn}, \mathrm{Fe}, \mathrm{Zn}$ and $\mathrm{Ca}$ in controlled and $10 \mu \mathrm{mol} / \mathrm{L} \mathrm{Pb}$ groups respectively

the affinity of $\mathrm{Pb}$ to nuclear proteins was significantly higher than the other fractions. Meanwhile, ${ }^{54} \mathrm{Mn}$, a radioactive tracer, was utilized to quantify $\mathrm{Mn}$ content in cell extracts after cellular extraction and found to be also present in the nuclei of Z310 cells (Kalia et al. 2008). Thus, we posited that nucleus may be the habitat for many heavy metals, not just for $\mathrm{Pb}$. However, a relatively small amount of heavy metals in other fractions should not rule out the importance of some organelle in metal-induced toxicity.

Initially, $\mathrm{Pb}$ was found to exist in $\mathrm{Pb}$-protein complexes of intranuclear inclusion bodies in various cells in the 1970s (Goyer et al. 1970; Moore and Goyer 1974; Shirabe and Hirano 1977). A major protein, p32/6.3, was identified in the $\mathrm{Pb}$-induced intranuclear inclusion bodies in kidney tubule-lining cells (Shelton and Egle 1982). Furthermore, the increased p32/6.3 under $\mathrm{Pb}$ 
A

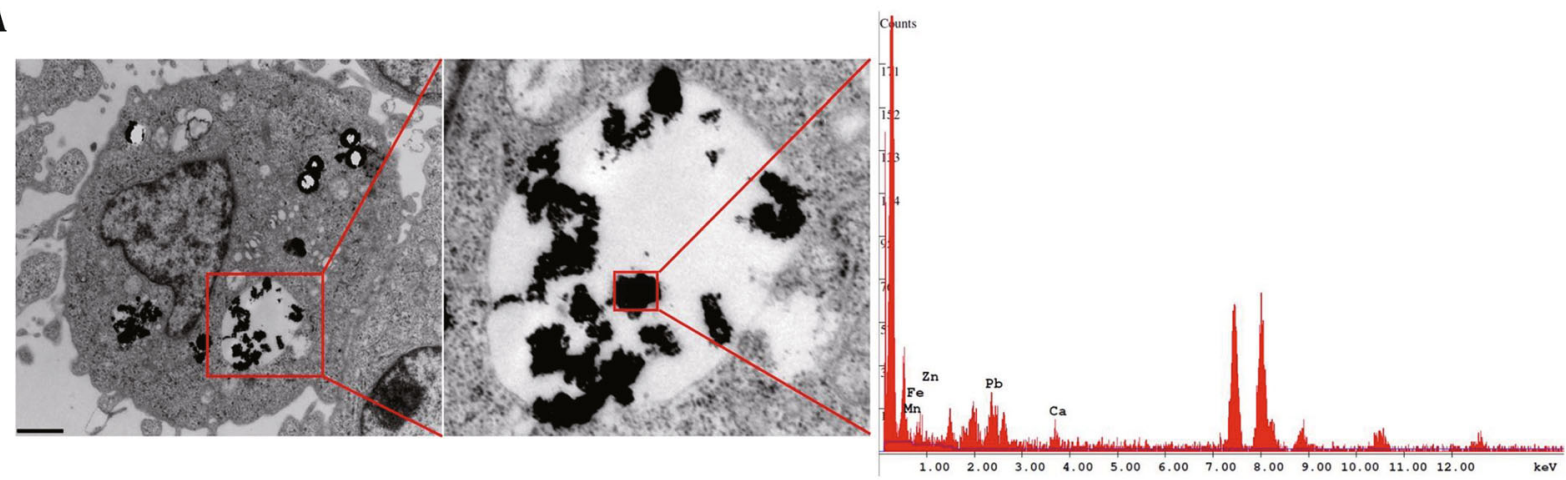

B

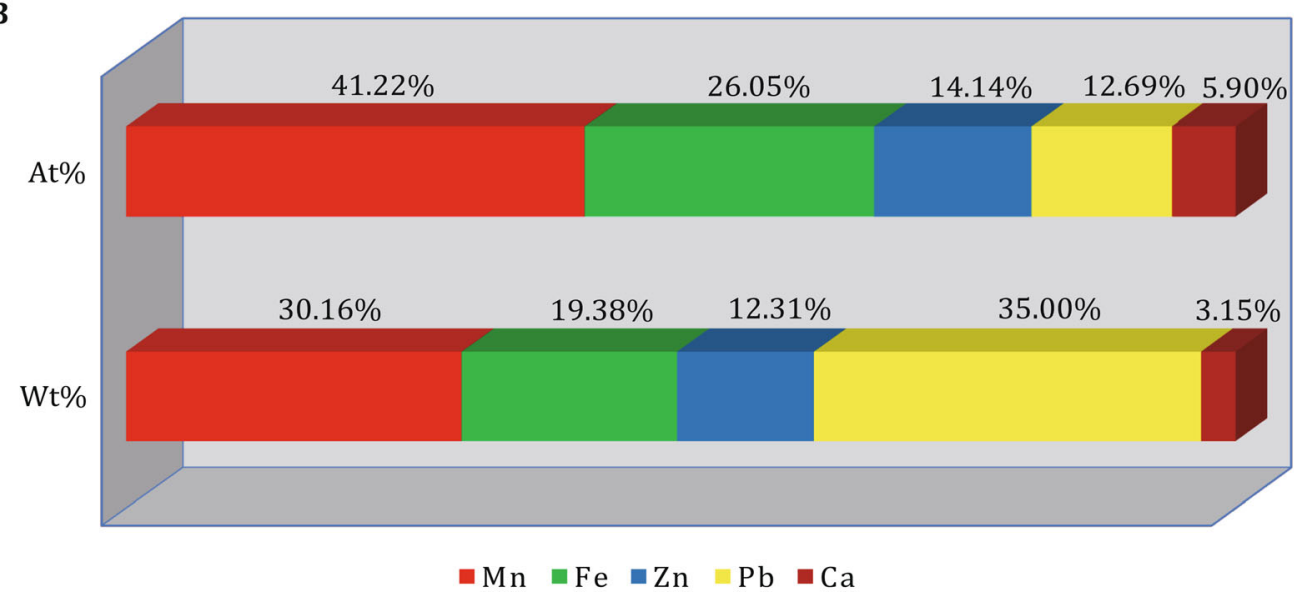

Fig. 4 EDS analysis of high-dose Pb-induced particles in the lysosomes. A Cellular localization of $200 \mu$ mol/L Pb monitored by electron microscopy. EDX analysis (right) of the large particles with high density outlined by red frame (middle) in the lysosome. The lysosome was also framed by the red line in the original cell (left). Scale bar is $1 \mu \mathrm{m}$. B Calculation of wt $\%$ and at $\%$ of $\mathrm{Pb}, \mathrm{Mn}, \mathrm{Fe}, \mathrm{Zn}$ and $\mathrm{Ca}$ in the indicated area

exposure in mouse neuroblastoma 2a (Nb2a) cells was attributed to decreased rate of degradation rather than increased transcription or translation (Klann and Shelton 1989). Our results, though, revealed nuclear $\mathrm{Pb}$ accumulation at $10 \mu \mathrm{mol} / \mathrm{L}$ level, no obvious structures like inclusion bodies were observed in this area. Interestingly, the "invisible" $\mathrm{Pb}$ could be detected with EDS technique and further confirmed by AMG staining. Apparent discrepancies between our findings of cytoplasmic lysosomes packaging xenobiotics with high electron density under $200 \mu \mathrm{mol} / \mathrm{L} \mathrm{Pb}$ exposure and intranuclear inclusion bodies in earlier studies may be due to tissue variability. The constituent ratio of $\mathrm{Mn}$ and $\mathrm{Pb}$ among such five elements took the majority in the black dots of the lysosomes through analysis of EDS. In a recent study, $\alpha$-synuclein was found to be regulated by metallothionein, a component of $\mathrm{Pb}$-induced inclusion bodies (Zuo et al. 2009). Moreover, $\alpha$-synuclein served a binding protein for divalent metal ions including $\mathrm{Fe}$ and Mn (Binolfi et al. 2006). Thus, co-existence of $\mathrm{Mn}, \mathrm{Pb}$, even $\mathrm{Fe}$ and $\mathrm{Zn}$ in the lysosomes in our study may derive from some protein with high-affinity to divalent metal ions.

In summary, the present study proposes a novel approach to localize ultra-structural $\mathrm{Pb}$ in cultured cells. What needs to be further investigated is its effectiveness in studying other heavy metal ions in different cells. We hope that this approach may be of reference for colocalization study of proteins and heavy metal ions in future studies of metal toxicology.

\section{MATERIALS AND METHODS}

\section{Materials}

$\mathrm{Pb}$ acetate $\left[\mathrm{Pb}(\mathrm{AC})_{2}\right]$ was obtained from Sigma (Saint Louis, MO, USA). Dulbecco's modified Eagle's medium (DMEM), RPMI 1640 medium, isometric lymphocyte separation medium, alpha minimum essential medium ( $\alpha$-MEM) with L-glutamine, Ham's F10 (H-F10) with Lglutamine, geneticin (G418), penicillin, streptomycin, 

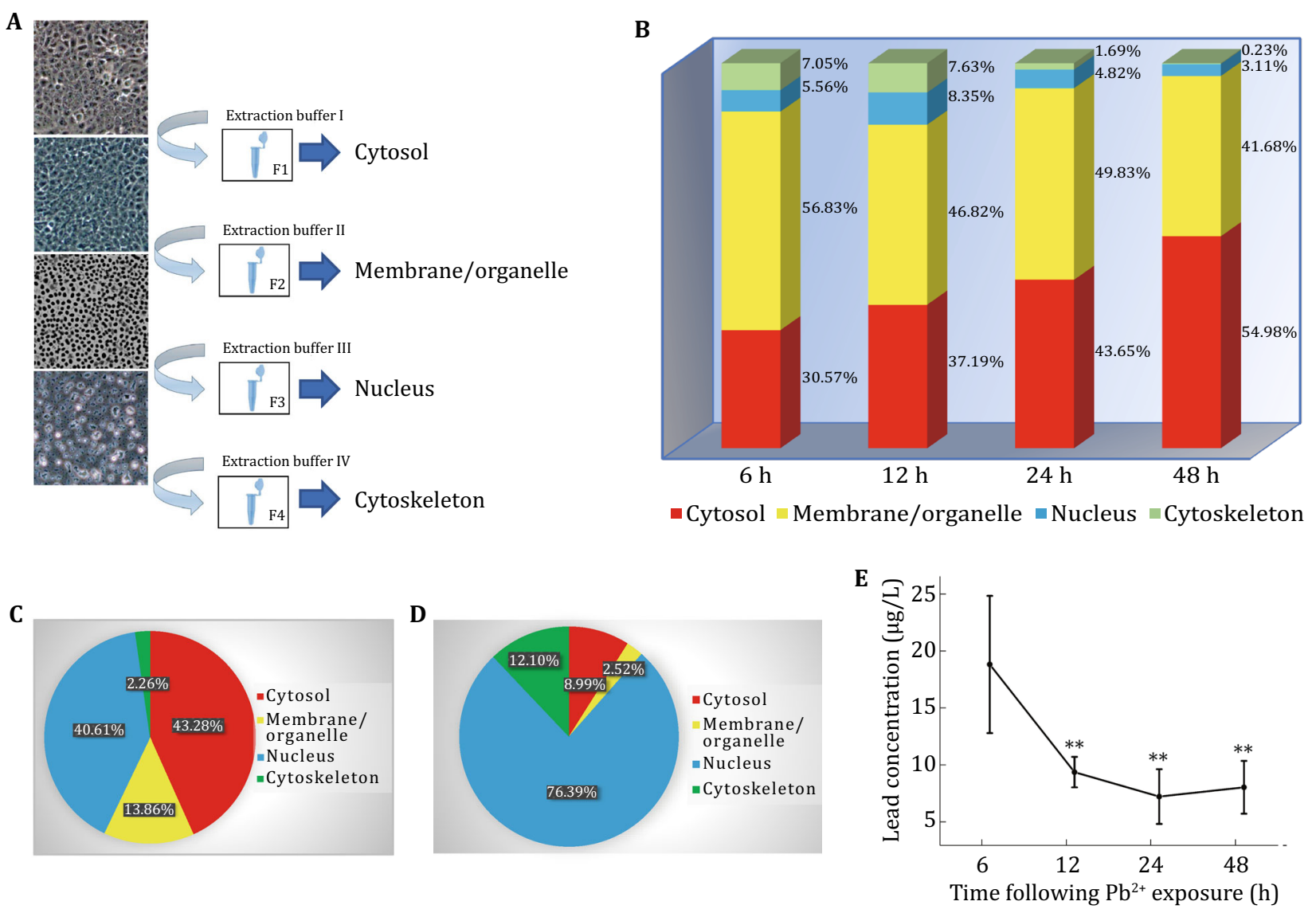

Fig. $5 \mathrm{~Pb}$ and protein content in subcellular distributions. A The process of extraction of cytosol, membrane/organelle, nucleus and cytoskeleton fractions in Z310 cells. The cell morphology was recorded before each step. B Hundred-percent bar chart of proteins in four fractions 6, 12, 24 or $48 \mathrm{~h}$ after $\mathrm{Pb}$ exposure. C Pie chart of Pb content in such fractions after $24 \mathrm{~h}$ exposure. D Pie chart of Pb percentage justified by the protein amount after $24 \mathrm{~h}$ exposure. $\mathbf{E}$ Pb concentrations in the nucleus fraction in Z310 cells treated with $10 \mu \mathrm{mol} / \mathrm{L}$ of $\mathrm{Pb}$ for $6,12,24$ and $48 \mathrm{~h}$. Asterisks depict a statistically significant difference $(p<0.01)$ compared with $6 \mathrm{~h}$ data (E) with one-way ANOVA. Data shown are representative of three independent experiments

gentamycin and $0.25 \%$ trypsin-EDTA were purchased from Invitrogen (Carlsbad, CA, USA). Basic fibroblast growth factor (bFGF) was obtained from MACGENE (Beijing, China). All reagents were analytical grade, HPLC grade, or the highest pharmaceutical grade available.

\section{Cell culture}

Z310 choroidal epithelial cells were cultured as previously described (Zheng et al. 2014; Zheng and Zhao 2002). Briefly, the cells were grown in DMEM supplemented with $10 \%$ FBS, 100 units $/ \mathrm{mL}$ penicillin, $100 \mu \mathrm{g} / \mathrm{mL}$ streptomycin, and $10 \mu \mathrm{g} / \mathrm{mL}$ of gentamycin in a humidified incubator with $95 \%$ air and $5 \% \mathrm{CO}_{2}$ at $37{ }^{\circ} \mathrm{C}$. Trypsin-EDTA was used to digest cells during subculture and Z310 cells were passaged (1:12-16) twice a week. When treated with $\mathrm{Pb}, 0,2.5,5,10,15,20$,
50 or $100 \mu \mathrm{mol} / \mathrm{L} \mathrm{Pb}(\mathrm{AC})_{2}$ was added to the cells $24 \mathrm{~h}$ after initial seeding, and the following studies were performed. The rat brain microvascular endothelial cell line RBE4 was cultured as previously described (Song et al. 2014).

\section{Electron microscopic AMG}

Z310 cells (in $100-\mathrm{mm}$ plates) were seeded with a density of $1 \times 10^{6}$ per plate and treated with $10 \mu \mathrm{mol} / \mathrm{L} \mathrm{Pb}$ for $24 \mathrm{~h}$. Cells were collected into $1.5-\mathrm{mL}$ EP tubules after digestion with trypsin-EDTA and incubated with $5 \%$ bovine serum albumin (BSA) on ice for $10 \mathrm{~min}$. Supernatants were discarded after centrifugation (350 g for $10 \mathrm{~min}$ ). Cell pellets were fixed with $3 \%$ glutaraldehyde (GA) for $3 \mathrm{~h}$ at room temperature. After treatment of $1 \%$ sodium sulfide solutions (11.79 g sodium sulfide nonahydrate and 13.7 g sodium 
A

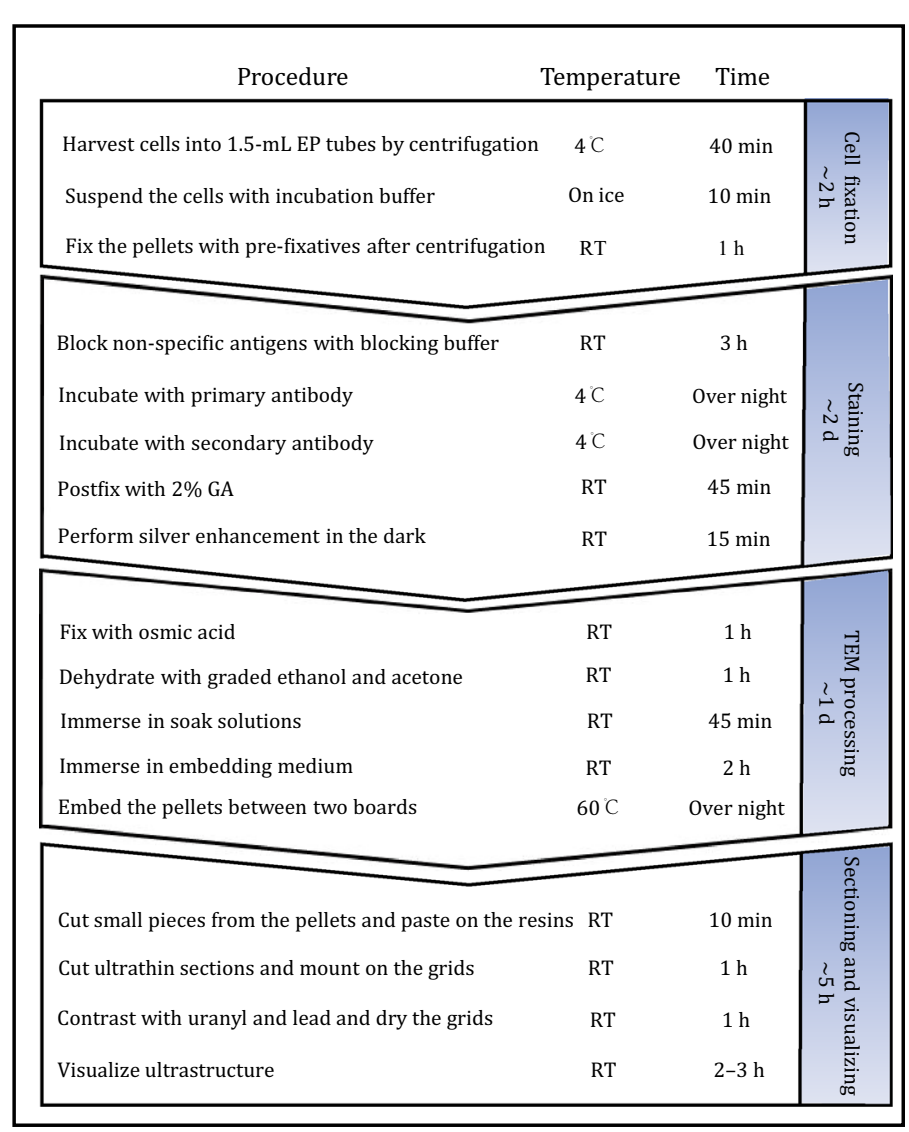

B

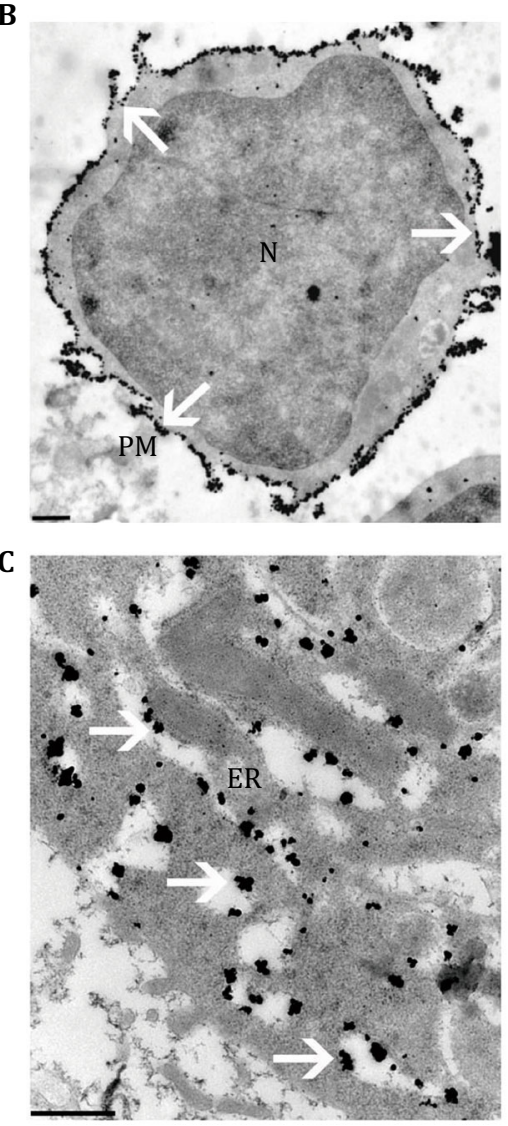

Fig. 6 A Flow chart with both time and temperature needed in the main procedures of the four parts. "RT": room temperature, "GA": glutaraldehyde. B CD20 localization in human B-lymphocytes. Mouse monoclonal anti-CD20 antibody and goat anti-mouse IgG conjugated to $1.4 \mathrm{~nm}$ gold particles were used as the primary and secondary antibody respectively. White arrows point to the localization of CD20. "N" represents nucleus and "PM" represents plasma membrane. C GRP78 localization in RBE4 cells. Rabbit polyclonal anti-GRP78 antibody and goat anti-rabbit IgG conjugated to $1.4 \mathrm{~nm}$ gold particles were used as the primary and secondary antibody respectively. White arrows point to the localization of GRP78. "ER" represents endoplasmic reticulum. Scale bars, $0.5 \mu \mathrm{m}$

dihydrogen phosphate dihydrate dissolved up to $1000 \mathrm{~mL}$ distilled water) for $7 \mathrm{~min}, \mathrm{AMG}$ developer was used to incubate the pellets at $26^{\circ} \mathrm{C}$ for $30 \mathrm{~min}$. The AMG developer consists of $60 \mathrm{~mL} 50 \%$ gum arabic solution, $10 \mathrm{~mL}$ sodium citrate buffer $(25.5 \mathrm{~g}$ citric acid hydrate and $23.5 \mathrm{~g}$ sodium citrate dihydrate dissolved up to $100 \mathrm{~mL}$ distilled water), $15 \mathrm{~mL}$ reductor $(0.85 \mathrm{~g}$ hydroquinone in $15 \mathrm{~mL}$ distilled water at $40{ }^{\circ} \mathrm{C}$ ) and $15 \mathrm{~mL}$ silver nitrate solution $(0.12 \mathrm{~g}$ silver lactate in $15 \mathrm{~mL}$ distilled water at $40{ }^{\circ} \mathrm{C}$ ). The developer was prepared by mixing the four parts immediately before use (Danscher 1981; Danscher and Stoltenberg 2006). The gum arabic, a protecting colloid in the silver lactate developer, is essential when developing time exceeds $30 \mathrm{~min}$.

The process was stopped by $5 \%$ sodium thiosulphate solutions for $10 \mathrm{~min}$. The samples were then post-fixed with $0.5 \%$ osmium tetroxide in $0.1 \mathrm{~mol} / \mathrm{L}$ phosphate buffer (PB) for $1 \mathrm{~h}$, dehydrated in graded series of ethanol, then in propylene oxide, and finally flat-embedded in
Epon 812 (SPI-CHEM, West Chester, PA, USA). Ultrathin Sections (50-70 nm) were cut with an ultramicrotome (EM UC6, Leica) and mounted on copper grids (6-8 sections/grid). Sections were then counter-stained with uranyl acetate and $\mathrm{Pb}$ citrate, and observed under a JEM-1230 electron microscopy (JEOL LTD, Tokyo, Japan). Electron micrographs were captured by the Gatan digital camera and its application software (832 SC1000, Gatan, Warrendale, PA, USA). Operative skills are further illustrated by a diagrammatic sketch in Fig. 1 .

\section{Cell preparation for transmission electron microscopy (TEM)}

Z310 cells were washed three times with PBS followed by digestion with $0.25 \%$ trypsin-EDTA for $4 \mathrm{~min}$. Cells were collected into microcentrifuge tubes, followed by centrifugation (350 $\mathrm{g}$ for $10 \mathrm{~min}$ ). Cell pellets were fixed with $3 \%$ GA for $3 \mathrm{~h}$ at room temperature. The samples were fixed with $0.5 \%$ osmium tetroxide in $0.1 \mathrm{~mol} / \mathrm{L} \mathrm{PB}$ 
for $1 \mathrm{~h}$, dehydrated in graded series of ethanol, then in propylene oxide, and finally flat-embedded in Epon 812 . Ultrathin Sections $(100 \mathrm{~nm})$ were cut with the ultramicrotome and mounted on nickel mesh grids (6-8 sections/grid). Hitachi electron microscopy (H-7650; Hitachi Ltd., Tokyo, Japan) was used for observation of sections and EDS that can be used to calculate the constituent ratio including weight percent (wt\%) and atom percent (at\%) of metallic elements.

\section{Subcellular fractionation}

According to the manufacturer's directions, cells were fractionated into cytosol, membrane/organelle, nucleus and cytoskeleton using a ProteoExtract ${ }^{\circledR}$ Subcellular Proteome Extraction Kit (Merck Millipore, German). The constituent ratios of protein in such four fractionations were calculated through the product of protein concentrations and corresponding volumes. Protein concentrations were analyzed with Pierce ${ }^{\circledR}$ BCA Protein Assay Kit (Thermo Scientific, USA).

\section{Cell $\mathrm{Pb}$ concentrations measurement}

After $\mathrm{Pb}$ treatment, cells were collected into $1.5-\mathrm{mL}$ EP tubules. Concentrated nitric acids were utilized for nitrolysis at $100{ }^{\circ} \mathrm{C}$ for $1 \mathrm{~h}$. $\mathrm{Pb}$ concentrations were standardized by cell numbers. Before detection, we created a calibration curve and ensured that the concentrations were distributed within the linear range. Aliquots of nitrolysis products were used for measurement of cell $\mathrm{Pb}$ concentrations expressed as micrograms per deciliter $(\mu \mathrm{g} / \mathrm{L})$ by graphite furnace atomic absorption spectroscopy (AAS, PinAAcle-Model 900TAtomic Absorption Spectrometer, PerkinElmer, USA).

\section{Isolation of B-lymphocytes}

Human peripheral venous blood was donated by our group to isolate B-lymphocytes. The blood was mixed at 3:1 with pre-warmed RPMI 1640 medium in EDTAcontaining tubes. The mixture was laid gently onto isometric lymphocyte separation medium. Peripheral blood mononuclear cells including B-lymphocytes were transferred with Pasteur pipettes into 50-mL EP tubes from the ring-shape interphase after centrifugation (slow acceleration, no brake). The cells were washed with RPMI 1640 medium, followed by centrifugation ( $100 \mathrm{~g}$ for $10 \mathrm{~min}$; fast acceleration, fast brake).

\section{Statistical analysis}

All data are reported as the mean \pm SD from at least three independent biological samples. Statistical significance between multiple groups was performed using one-way analysis of variance (ANOVA) followed by twotailed paired Student's $t$-tests to compare individual groups. Values of $p<0.01$ were considered statistically significant.

$\begin{array}{ll}\text { Abbreviations } \\ \text { AAS } & \text { Atomic absorption spectroscopy } \\ \text { AMG } & \text { Autometallography } \\ \text { BBB } & \text { Blood-brain barrier } \\ \text { BCB } & \text { Blood-CSF barrier } \\ \text { BSDs } & \text { Black silver deposits } \\ \text { CSF } & \text { Cerebrospinal fluid } \\ \text { EDS } & \text { Energy-dispersive X-ray spectroscope } \\ \text { NMDAR } & N \text {-Methyl-D-aspartic acid receptor } \\ \text { TEM } & \text { Transmission electron microscopy }\end{array}$

Acknowledgements We thank Professor Xiao-Feng Huang for his great suggestions on electron microscopic AMG, Nai-ning Lu and Jin-Yan Zhang for their assisting on preparation of the ultrathin sections, Yao-ming Chen for analysis of AAS, the staffs of Electron Microscopy Center in Xi'an Jiaotong University for EDS detection, and Professor Wei-ming Ouyang for English revising. This work was supported by the National Basic Research Program of China (973 Program) (2012CB525002); the National Natural Science Foundation of China (81230063 and 81172700); in part by the Program for Changjiang Scholars and Innovative Research Team in University (PCSIRT); NIH Grants ES-R0110563 and ES-R0107331.

\section{Compliance with Ethical Standards}

Conflict of interest Han Song, Gang Zheng, Xue-Feng Shen, ZaiHua Zhao, Yang Liu, Yang Liu, Ying-Ying Liu, Jun-Jun Kang, JingYuan Chen and Wen-Jing Luo declare that they have no conflict of interest.

Human and animal rights and informed consent All procedures followed were in accordance with the ethical standards of the Responsible Committee on Human Experimentation (Institutional and National) and with the Helsinki Declaration of 1975, as revised in 2000 (5). Informed consent was obtained from all participants for being included in this study.

Open Access This article is licensed under a Creative Commons Attribution 4.0 International License, which permits use, sharing, adaptation, distribution and reproduction in any medium or format, as long as you give appropriate credit to the original author(s) and the source, provide a link to the Creative Commons licence, and indicate if changes were made. The images or other third party material in this article are included in the article's Creative Commons licence, unless indicated otherwise in a credit line to the material. If material is not included in the article's Creative Commons licence and your intended use is not permitted 
by statutory regulation or exceeds the permitted use, you will need to obtain permission directly from the copyright holder. To view a copy of this licence, visit http://creativecommons.org/ licenses/by/4.0/.

\section{References}

Akinyemi A, Miah M, Ijomone O, Tsatsakis A, Soares F, Tinkov A, Skalny A, Venkataramani V, Aschner M (2019) Lead (Pb) exposure induces dopaminergic neurotoxicity in Caenorhabditis elegans: involvement of the dopamine transporter. Toxicol Rep 6:833-840

Basha D, Rani M, Devi C, Kumar M, Reddy G (2012) Perinatal lead exposure alters postnatal cholinergic and aminergic system in rat brain: reversal effect of calcium co-administration. Int J Dev Neurosci 30:343-350

Behl M, Zhang Y, Shi Y, Cheng J, Du Y, Zheng W (2010) Leadinduced accumulation of $\beta$-amyloid in the choroid plexus: role of low density lipoprotein receptor protein-1 and protein kinase C. Neurotoxicology 31:524-532

Binolfi A, Rasia RM, Bertoncini CW, Ceolin M, Zweckstetter M, Griesinger C, Jovin TM, Fernández CO (2006) Interaction of $\alpha$ synuclein with divalent metal ions reveals key differences: a link between structure, binding specificity and fibrillation enhancement. J Am Chem Soc 128:9893-9901

Boucher O, Burden MJ, Muckle G, Saint-Amour D, Ayotte P, Dewailly É, Nelson CA, Jacobson SW, Jacobson JL (2012) Response inhibition and error monitoring during a visual go/ no-go task in Inuit children exposed to lead, polychlorinated biphenyls, and methylmercury. Environ Health Perspect 120:608-615

Calderón J, Navarro ME, Jimenez-Capdeville ME, Santos-Diaz MA, Golden A, Rodriguez-Leyva I, Borja-Aburto V, Díaz-Barriga F (2001) Exposure to arsenic and lead and neuropsychological development in Mexican children. Environ Res 85:69-76

Chodobski A, Szmydynger-Chodobska J (2001) Choroid plexus: target for polypeptides and site of their synthesis. Microsc Res Tech 52:65-82

Danscher G (1981) Light and electron microscopic localization of silver in biological tissue. Histochemistry 71:177-186

Danscher G, Møller-Madsen B (1985) Silver amplification of mercury sulfide and selenide: a histochemical method for light and electron microscopic localization of mercury in tissue. J Histochem Cytochem 33:219-228

Danscher G, Stoltenberg M (2006) Silver enhancement of quantum dots resulting from (1) metabolism of toxic metals in animals and humans, (2) in vivo, in vitro and immersion created zincsulphur/zinc-selenium nanocrystals, (3) metal ions liberated from metal implants and particles. Prog Histochem Cytochem 41:57-139

Dimitriadis VK, Domouhtsidou GP, Raftopoulou E (2003) Localization of $\mathrm{Hg}$ and $\mathrm{Pb}$ in the palps, the digestive gland and the gills in Mytilus galloprovincialis (L.) using autometallography and X-ray microanalysis. Environ Pollut 125:345-353

Domouhtsidou GP, Dimitriadis VK (2000) Ultrastructural localization of heavy metals $(\mathrm{Hg}, \mathrm{Ag}, \mathrm{Pb}$, and $\mathrm{Cu})$ in gills and digestive gland of mussels, Mytilus galloprovincialis (L.). Arch Environ Contam Toxicol 38:472-478

Friedheim E, Corvi C, Graziano J, Donnelli T, Breslin D (1983) Choroid plexus as protective sink for heavy metals? Lancet 321:981-982
Goyer RA, May P, Cates MM, Krigman MR (1970) Lead and protein content of isolated intranuclear inclusion bodies from kidneys of lead-poisoned rats. Lab Investig 22:245-251

Kalia K, Jiang W, Zheng W (2008) Manganese accumulates primarily in nuclei of cultured brain cells. Neurotoxicology 29:466-470

Kang JJ, Wei XY, Liu JP, Wong-Riley MT, Ju G, Liu YY (2013) Expression of phosphor- $\left(\mathrm{Ca}^{2+}\right) /$ calmodulin-dependent protein kinase II in the pre-Bötzinger complex of rats. J Neurochem 126:349-359

Klann E, Shelton KR (1989) The effect of lead on the metabolism of a nuclear matrix protein which becomes prominent in lead-induced intranuclear inclusion bodies. J Biol Chem 264:16969-16972

Levine S (1987) Choroid plexus: target for systemic disease and pathway to the brain. Lab Investig 56:231-233

Manton WI, Kirkpatrick JB, Cook JD (1984) Does the choroid plexus really protect the brain from lead? Lancet 2:351

Moore JF, Goyer RA (1974) Lead-induced inclusion bodies: composition and probable role in lead metabolism. Environ Health Perspect 7:121-127

Needleman HL, Riess JA, Tobin MJ, Biesecker GE, Greenhouse JB (1996) Bone lead levels and delinquent behavior. J Am Med Assoc 275:363-369

Oskarsson A, Fowler BA (1985) Effects of lead inclusion bodies on subcellular distribution of lead in rat kidney: the relationship to mitochondrial function. Exp Mol Pathol 43:397-408

O'Tuama LA, Kim CS, Gatzy JT, Krigman MR, Mushak P (1976) The distribution of inorganic lead in guinea pig brain and neural barrier tissues in control and lead-poisoned animals. Toxicol Appl Pharmacol 36:1-9

Shelton KR, Egle PM (1982) The proteins of lead-induced intranuclear inclusion bodies. J Biol Chem 257:11802-11807

Shi LZ, Zheng W (2007) Early lead exposure increases the leakage of the blood-cerebrospinal fluid barrier, in vitro. Hum Exp Toxicol 26:159-167

Shirabe T, Hirano A (1977) X-ray microanalytical studies of leadimplanted rat brains. Acta Neuropathol 40:189-192

Song H, Zheng G, Shen X, Liu X, Luo W, Chen J (2014) Reduction of brain barrier tight junctional proteins by lead exposure: role of activation of nonreceptor tyrosine kinase Src via chaperon GRP78. Toxicol Sci 138:393-402

Thomas JA, Dallenbach FD, Thomas M (1973) The distribution of radioactive lead $\left({ }^{210} \mathrm{~Pb}\right)$ in the cerebellum of developing rats. J Pathol 109:45-50

Tong S, Baghurst PA, Sawyer MG, Burns J, McMichael AJ (1998) Declining blood lead levels and changes in cognitive function during childhood: the Port Pirie Cohort Study. J Am Med Assoc 280:1915-1919

Wang Q, Luo W, Zheng W, Liu Y, Xu H, Zheng G, Da Z, Zhang W, Chen Y, Chen J (2007) Iron supplement prevents lead-induced disruption of the blood-brain barrier during rat development. Toxicol Appl Pharmacol 219:33-41

Wang T, Guan R, Liu M, Shen X, Chen J, Zhao M, Luo W (2016) Lead exposure impairs hippocampus related learning and memory by altering synaptic plasticity and morphology during juvenile period. Mol Neurobiol 53:3740-3752

Wirbisky S, Weber G, Lee J, Cannon J, Freeman J (2014) Novel dose-dependent alterations in excitatory GABA during embryonic development associated with lead $(\mathrm{Pb})$ neurotoxicity. Toxicol Lett 229:1-8

Zheng W (2001) Toxicology of choroid plexus: special reference to metal-induced neurotoxicities. Microsc Res Tech 52:89-103

Zheng W, Zhao Q (2002) Establishment and characterization of an immortalized Z310 choroidal epithelial cell line from murine choroid plexus. Brain Res 958:371-380 
Zheng W, Perry DF, Nelson DL, Aposhian HV (1991) Protection of cerebrospinal fluid against toxic metals by the choroid plexus. FASEB J 5:2188-2193

Zheng W, Blaner WS, Zhao Q (1999) Inhibition by lead of production and secretion of transthyretin in the choroid plexus: its relationship to thyroxine transport at the bloodCSF barrier. Toxicol Appl Pharmacol 155:24-31
Zheng G, Zhang J, Xu Y, Shen X, Song H, Jing J, Luo W, Zheng W, Chen J (2014) Involvement of CTR1 and ATP7A in lead (Pb)induced copper $(\mathrm{Cu})$ accumulation in choroidal epithelial cells. Toxicol Lett 225:110-118

Zuo P, Qu W, Cooper RN, Goyer RA, Diwan BA, Waalkes MP (2009) Potential role of $\alpha$-synuclein and metallothionein in leadinduced inclusion body formation. Toxicol Sci 111:100-108 